Original Research Paper

\title{
Selective Susceptibility of Human Bladder Transitional Cell Carcinoma T24 Cells towards NBD Peptide
}

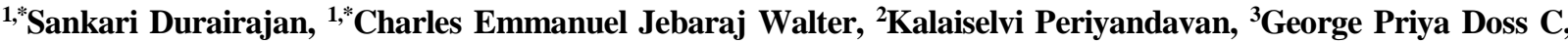 \\ ${ }^{4}$ Dicky John Davis G, ${ }^{5}$ Hannah Rachel Vasanthi A, ${ }^{6}$ Gayathri Thiruvengadam and ${ }^{7}$ Thanka Johnson \\ ${ }^{I}$ Department of Biotechnology, Faculty of Biomedical Sciences, Technology and Research, Sri Ramachandra Institute of \\ Higher Education and Research (Deemed to be University), Chennai, India \\ ${ }^{2}$ Department of Medical Biochemistry, Dr. ALM PG Institute of Basic Medical Sciences, University of Madras, Chennai, India \\ ${ }^{3}$ Department of Integrative Biology, School of Biosciences and Technology, VIT University, Vellore, India \\ ${ }^{4}$ Department of Bioinformatics, Faculty of Biomedical Sciences, Technology and Research, Sri Ramachandra Institute of \\ Higher Education and Research (Deemed to be University), Chennai, India \\ ${ }^{5}$ Department of Biotechnology, School of Life Sciences, Pondicherry University, Pondicherry, India \\ ${ }^{6}$ Faculty of Allied Health Sciences, Sri Ramachandra Institute of Higher Education and Research (Deemed to be University), \\ Chennai, India \\ ${ }^{7}$ Department of Pathology, SRMC\&RI, Sri Ramachandra Institute of Higher Education and Research, (Deemed to be \\ University), Chennai, India
}

Article history

Received: 17-01-2020

Revised: 06-03-2020

Accepted: 18-04-2020

Corresponding Author:

Charles Emmanuel Jebaraj Walter Department of Biotechnology, Faculty of Biomedical Sciences, Technology and Research, Sri Ramachandra Institute of Higher Education and Research (Deemed to be University), Chennai600116, India

Tel: +91-44-4592-8602

Email: cejwalter@sriramachandra.edu.in

*Authors have contributed equally

\section{Introduction}

Bladder Cancer (BC) is the second most common malignancy of the genitourinary system in industrialized
Abstract: Bladder cancer is a recurrent disease that often develops chemoresistance and is on the rise in developing countries. After diagnosis surgery followed by immunotherapy and/or chemo- radiation therapy are the available treatments. These treatments do not provide protection against disease progression or recurrence thus highlighting the need to identify and develop drugs that are capable of inhibiting bladder cancer. T24 cell line (human bladder transitional cell carcinoma) was treated with NEMO Binding Domain (NBD) peptide and tested for its cytotoxicity, cell cycle inhibition, apoptosis and migration, in vitro. The cytotoxicity of NBD peptide was tested on non-cancerous cells (NIH-3T3-L1, CHO, Vero) and the peptide localization in T24 cells was confirmed using confocal microscopy. The effects of NBD peptide and the standard drugs (cisplatin, gemcitabine) were compared with untreated control. Peptide based chemotherapy for human bladder cells was tested that include combinations of NBD and standard drugs. Statistical significance was assessed between the different treatment groups. The viability of T24 cells after NBD peptide treatment was reduced to $50 \%$ at a dose of $18.5 \mu \mathrm{M}$ after $48 \mathrm{~h}$. The NBD peptide elicited selective cytotoxicity dose-dependently in T24 cells while being non-toxic on normal (non-cancer) cell lines. Sub G0-G1 accumulation of T24 cells was seen where they underwent necrosis and lost the ability to migrate when treated with $100 \mu \mathrm{M} \mathrm{NBD}$. T24 cell death increased to 78\% when treated with a combination of NBD with cisplatin and gemcitabine (standard drugs) as opposed to $\sim 50 \%$ when treated with NBD peptide alone. NBD peptide exhibits specific anti-cancer activity on T24 cells in vitro and found to be non-cytotoxic to select normal cell lines. Combining NBD with standard drugs demonstrated excellent inhibition of malignant growth than the individual anti-neoplastic agents.

Keywords: Urinary Bladder Neoplasms, Nemo Binding Domain (NBD), Anti-Tumor Drug Screening, Cisplatin, Gemcitabine 
modality (Jakobsson et al., 2018). BC incidence is based on genetic predisposition, lifestyle or environmental factors (Burger et al., 2012). BC is predominant in older male patients $\geq 65$ years of age at the time of diagnosis. Also, recurrence and chemoresistance are prevalent in BC (Lu et al., 2017; Wang et al., 2018; Woolbright et al., 2018). There are two major types of BC including the superficial disease and the invasive disease. Bacillus Calmette-Guerin (BCG) immunotherapy is the treatment offered after Transurethral Resection of Bladder Tumor (TURBT) for superficial BCs. Many investigations report $\mathrm{BCG}$ as effective in preventing $\mathrm{BC}$ recurrence (Pettenati and Ingersoll, 2018; Guallar-Garrido and Julián, 2020). However, it is still controversial when considering its ability to prevent $\mathrm{BC}$ progression (Kaufman et al., 2009; Buchwald and Efstathiou, 2015). Treatments offered for invasive BC are surgery with neoadjuvant-, adjuvant-, chemo- and radiation therapy which lacks in-depth analysis of the underlying mechanism due to the lack in the number of randomised Control Trials (RCT) performed for BC (Soloway, 2013). Thus it becomes important to identify the inherent heterogeneity and personalize treatment in $\mathrm{BC}$ by understanding the key players in its pathogenesis.

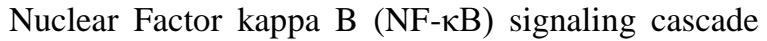
plays an important role in cell survival (Zhang et al.,

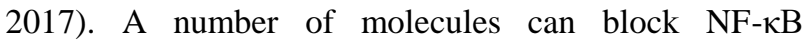
pathway and thus the critical node either directly or indirectly through its signaling pathway members to suppress cancer. Drugs that utilize this strategy are effective in reducing tumor but have poor clinical efficacy (Ianaro et al., 2009; Karin et al., 2002). Proteosome inhibitors are the only exception from this trait which is used for the treatment of some haematological malignancies that demonstrate the key role of NF- $\mathrm{BB}$ during their pathogenesis (Richardson et al., 2004). There are many reports stating the involvement of NF-кB in BC (Durairajan et al., 2018; Levidou et al., 2008; Mukherjee et al., 2015; Yeh et al., 2010). However, there are limited reports that have considered the NF- $\kappa \mathrm{B}$ signaling cascade and $\mathrm{BC}$ in a therapeutic setting. This study is the first of its kind to the best of our knowledge to consider NF- $\mathrm{NB}$ associated peptide as a treatment option for $\mathrm{BC}$. NF- $\kappa \mathrm{B}$ Essential Modulator (NEMO) is a regulatory protein that belongs to the NF$\kappa \mathrm{B}$ pathway. It allows catalytic units (IKK $\alpha, \operatorname{IKK} \beta)$ to bind in a region called NEMO Binding Domain (NBD) (May et al., 2000). This domain is termed NBD and is of significance since the core peptides are capable of eliciting NF- $\kappa B$ inhibitory effects. NBD has shown antiinflammatory activity (Baima et al., 2010) in murine models against colitis (Hong et al., 2012), rheumatoid arthritis/osteoclastogenesis (Jimi et al., 2004), kernicterus (Li et al., 2015) and pancreatitis in rats (Long et al., 2009) and also against canine refractory diffuse large B- cell lymphoma (Gaurnier-Hausser et al., 2011). The inherent heterogeneity of BC and the success rate behind $\mathrm{BCG}$ treatment establish the inflammatory milieu prevalence. Thus this preliminary in vitro study analyzes the potential held by NBD peptide as an antineoplastic agent in BC.

\section{Materials and Methods}

\section{Peptides, Reagents and Materials}

NBD peptide (TTLDWSWLQME) according to Dai et al. (2004), FITC-NBD (FITCYGRKKRRQRRR-G- TTLDWSWLQME) and TAT (YGRKKRRQRRR) peptides were procured from Genscript (NJ, USA). The physical and chemical properties of the peptides were characterized before use. Dimethyl Sulfoxide (DMSO), propidium iodide (PI), Cisplatin (C), Gemcitabine (G), Triton X-100, RNase, MTT reagent, sodium pyruvate, lithium lactate, NAD+, acridine orange (AO), DAPI (4', 6- Diamidino2-phenyl indole) and ethidium bromide (EtBr) were purchased from Sigma-Aldrich (St. Louis, MO, USA). McCoy's 5A Medium, DMEM, Trypsin-EDTA, HEPES (4-(2-hydroxyethyl)-1-piperazine ethane sulfonic acid), L-Glutamine and Fetal Bovine Serum (FBS) were procured from Gibco (BRL, CA, USA). A EnzChek® Caspase-3 Assay Kit \#2 (Molecular Probes: MP 13184) was purchased from Thermo Scientific (Rockford, IL, USA). All other common reagents were procured from HiMedia Laboratories Pvt. Ltd. (Mumbai, India).

\section{Cell Culture and Treatment}

T24 cell line (Human transitional cell carcinoma of the urinary bladder), NIH-3T3-L1 (mice fibroblasts), CHO (Chinese Hamster Ovary) and Vero (African green monkey kidney) were obtained from the National Centre for Cell Science (NCCS), Pune, India. T24 cells are resistant to cisplatin and were cultured as monolayers in McCoy's 5A medium. NIH-3T3-L1, $\mathrm{CHO}$ and Vero were cultured in DMEM. Each of the medium used for maintenance was supplemented with $10 \%$ FBS, L-Glutamine and $3 \mathrm{mM}$ sodium bicarbonate/ $20 \mathrm{mM}$ HEPES. A combination of antibiotics (penicillin, streptomycin, kanamycin) and an antimycotic (amphotericin B) was used. The cells were maintained at $37^{\circ} \mathrm{C}$ with $5 \% \quad \mathrm{CO}_{2}$ and $85-95 \%$ humidity. The maintained cultures were subcultured for assays and drug treated at optimal growth (Abdel-Mageed, 2003; Chong et al., 2000).

NBD was prepared in serum free McCoy's 5A medium and used for treatment. TAT is a cell 
penetrating peptide (Trans-Activator of Transcription protein derived from human immunodeficiency virus) tagged to NBD peptide to ensure cell entry. It was employed as a vehicle control at a final concentration not exceeding $100 \mu \mathrm{M}$ in the cell culture experiments. The standard drug, cisplatin was prepared in $0.9 \%$ sodium chloride to avoid isomerisation, kept protected from light and used at a final concentration of $50 \mu \mathrm{M}$ (Tian et al., 2008). Gemcitabine was prepared in serum free McCoy's 5A medium and used at a final concentration of $50 \mathrm{nM}$ in the cell culture experiments (Fechner et al., 2003). Based on the half maximal inhibitory concentration $\left(\mathrm{IC}_{50}\right)$ of NBD peptide, all treatments were carried out and incubated for $48 \mathrm{~h}$ along with select concentrations: $12.5,25,50$ and/or $100 \mu \mathrm{M}$ in every experiment, except for confocal microscopy where 20 $\mu \mathrm{M}$ FITC-NBD was used.

\section{Confocal Microscopy for Localization}

T24 cells were seeded on a coverslip placed inside a $35 \mathrm{~mm}$ Petri dish at a concentration of $1 \times 10^{4}$ cells. McCoy's 5A medium was added and incubated to attain $80 \%$ confluency. FITC tagged NBD peptide (20 $\mu \mathrm{M})$ was treated for different time periods (10 min, 45 min, $4 \mathrm{~h}$ and $24 \mathrm{~h}$ ). The plates were incubated in the dark at $37^{\circ} \mathrm{C}$ for the designated durations and counterstained with $10 \mu \mathrm{L}$ PI $(1 \mathrm{mg} / \mathrm{mL})$ for $1 \mathrm{~min}$. The coverslips were briefly rinsed with PBS and mounted onto another coverslip for documentation according to the previous report with slight modifications (Choi et al., 2003).

\section{Cell Proliferation and Viability Assessment by MTT Assay}

T24, NIH-3T3-L1, CHO and Vero cells were seeded at a concentration of $1 \times 10^{4}$ cells/well on a 96 well plate with $10 \%$ medium. At about $80 \%$ confluency, different concentrations of the NBD peptide $(12.5,25$ and 50 $\mu \mathrm{M})$, TAT peptide $(100 \mu \mathrm{M})$ as vehicle control and standard drugs (Cisplatin, $50 \mu \mathrm{M}$ and Gemcitabine, 50 $\mathrm{nM}$ ) were treated and the volume was made up to 100 $\mu \mathrm{L}$. The drug treated plates were incubated for $48 \mathrm{~h}$ at $37^{\circ} \mathrm{C}$ for cell proliferation and viability assessment. Finally, $20 \mu \mathrm{L}$ of MTT reagent $(1 \mathrm{mg} / \mathrm{mL})$ was added and incubated for $4 \mathrm{~h}$ at $37^{\circ} \mathrm{C}$ for quantification. The purple formazan crystals formed were dissolved using $100 \%$ DMSO and read at $570 \mathrm{~nm}$ in BMG Fluostar Optima multimode reader (Wang et al., 2012). The $\mathrm{IC}_{50}$ value for NBD peptide on T24 cells was determined from the MTT experiment. Synergistic action of $\mathrm{IC}_{50}$ NBD peptide was tested with a combination of standard drugs. The tested combinations are $\mathrm{IC}_{50} \mathrm{NBD}$ and cisplatin; $\mathrm{IC}_{50} \mathrm{NBD}$ and gemcitabine; $\mathrm{IC}_{50} \mathrm{NBD}$, cisplatin and gemcitabine.

\section{Cell Cycle Analysis Using Flow Cytometry}

T24 cells were seeded at a concentration of $1 \times 10^{5}$ cells/ well on a 12 well plate and allowed to attain confluency. Different concentrations of the NBD peptide: $12.5,18.5\left(\mathrm{IC}_{50}\right), 25 \mu \mathrm{M}$, TAT and standard drugs were treated. Combinations of NBD peptide along with the standard drugs were also treated. The plates were incubated at $48 \mathrm{~h}$ at $37^{\circ} \mathrm{C}$, harvested by trypsinization, rinsed with $\mathrm{PBS}$ and centrifuged at 1500 rpm for $10 \mathrm{~min}$. Cells were fixed overnight at $4{ }^{\circ} \mathrm{C}$ in ice-cold alcohol (70\%). The fixed cells were washed with PBS and centrifuged at $1500 \mathrm{rpm}$ for $10 \mathrm{~min}$ before analysis. Triton X-100 (0.5\%) and RNase $(0.1$ $\mathrm{mg} / \mathrm{mL}$ ) was added and incubated for an hour. Propidium iodide $(40 \mu \mathrm{g} / \mathrm{mL})$ was added to the mix and incubated for $45 \mathrm{~min}$ in the dark. Cell cycle analysis was carried out on FACS Calibur (BD Biosciences) (Ma et al., 2009; Wang et al., 2013).

\section{Assessing Cell Death by Acridine Orange/Ethidium Bromide (AO/ EtBr) Fluorescence Staining Assay}

T24 cells were seeded at a concentration of $1 \times 10^{5}$ cells/well on a 6 -well plate added with $10 \%$ medium and allowed to attain confluency. NBD (12.5, 18.5 and $25 \mu \mathrm{M}$ ), TAT peptide, standard drugs and the combination were treated. The plates were incubated at $48 \mathrm{~h}$ at $37^{\circ} \mathrm{C}$ followed by addition of $10 \mu \mathrm{L}$ $\mathrm{AO} / \mathrm{EtBr}(1 \mathrm{mg} / \mathrm{mL})$ to each well for morphological documentation (Ishaq et al., 2014). The fluorescence screen was applied and the cells were photographed under a microscope (Nikon Eclipse Ti-S, USA).

\section{Caspase-3 Activity}

Quantification of caspase-3 release was carried out according to the EnzChek ${ }^{\circledR}$ Caspase-3 Assay Kit \#2 (Molecular Probes: MP 13184) protocol. Briefly, T24 cells at $1 \times 10^{4}$ cells per well were resuspended in 50 $\mu \mathrm{L}$ of the $1 \times$ cell lysis buffer. Cells were incubated on ice for about $30 \mathrm{~min}$ to ensure optimal lysis. After incubation, the cells were centrifuged at $5000 \mathrm{rpm}$ for $5 \mathrm{~min}$ in a centrifuge. Then $50 \mu \mathrm{L}$ of the supernatant from each sample was transferred to individual microplate wells. $1 \times$ cell lysis buffer $(50 \mu \mathrm{L})$ was used as a "no-enzyme control" to determine the background fluorescence. Then $50 \mu \mathrm{L}$ of $2 \times$ substrate working solution was added to each sample (NBD: $100 \mu \mathrm{M}, \mathrm{NBD}$ and standard drug combination) and untreated control. The microplate was covered and incubated at room temperature for $30 \mathrm{~min}$. Fluorescence was measured on a microplate reader (BMG FLUOSTAR OPTIMA multimode reader) using excitation/emission wavelengths of 492/520 nm (Cerón et al., 2010). 


\section{Cellular Damage Detection Using Lactate Dehydrogenase (LDH) Release}

T24 cells were seeded on 48 -well plates at a density of $2.5 \times 10^{4}$ cells/well and allowed to become confluent overnight. At $>80 \%$ confluency, the cells were treated with NBD peptide for $48 \mathrm{~h}$ along with standard drugs and vehicle control. After treatment, the conditioned media was used to assess the LDH released by the damaged cells. Buffered substrate $(1 \mathrm{~mL})$ and conditioned media $(0.1 \mathrm{~mL})$ was added and incubated at $37^{\circ} \mathrm{C}$ (in a water bath). To this mix, $0.2 \mathrm{~mL}$ of NAD+ solution was added, mixed gently and incubated at $37^{\circ} \mathrm{C}$ for $15 \mathrm{~min}$. DNPH reagent $(1 \mathrm{~mL})$ was added and incubated further for $15 \mathrm{~min}$. Finally, $10 \mathrm{~mL}$ of sodium hydroxide $(0.4 \mathrm{~N})$ was added and the absorbance was read at $440 \mathrm{~nm}$. Standards were also run parallelly and treated as for assays with sodium pyruvate. The amount of color developed was directly proportional to the number of lysed cells (Elumalai et al., 2012).

\section{Detection of Apoptosis by DAPI Staining}

T24 cells were seeded on 12-well plates at a density of $5 \times 10^{4}$ cells/well and allowed to become confluent overnight. For the nuclear changes, the monolayer of cells was washed with PBS, fixed with 3\% paraformaldehyde $(10 \mathrm{~min})$ and were permeabilized with $0.2 \%$ Triton X-100 in PBS (10 min) at ambient temperature. The cells were finally incubated with 0.5 $\mu \mathrm{g} / \mathrm{mL}$ of DAPI for $5 \mathrm{~min}$ to identify the apoptotic nuclei which were intensely stained or fragmented or had condensed chromatin. The changes were observed and recorded under a fluorescent microscope (ex $359 \mathrm{~nm}$; em $461 \mathrm{~nm}$ ) (Tajmohammadi et al., 2019).

\section{Wound Healing Assay}

T24 cells were seeded at a concentration of $1 \times 10^{5}$ cells/well on a 6-well plate and allowed to attain confluency before treatment. Confluent monolayers were wounded by physical shearing across the well using a sterile micropipette tip. The diameter of the wound inflicted was measured immediately using a phase contrast microscope (Nikon Eclipse Ti-S) with ImagePro software. NBD (18.5 and $100 \mu \mathrm{M})$, TAT peptide, standard drugs and the combination were treated. The plates were incubated for $60 \mathrm{~h}$ at $37^{\circ} \mathrm{C}$, observed for wound closure and documented (Gao et al., 2006).

\section{Statistical Analysis}

All the experiments were repeated thrice for accuracy and each sample was assessed in triplicates. The data are presented as the mean \pm SD. Statistical analysis was performed with IBM SPSS Statistics 23v and differences between groups were examined using one-way Analysis of Variance (ANOVA) followed by Tukey's multiple comparison test wherever applicable to prove statistical significance. $P$ value of $\leq 0.05$ was considered statistically significant.

\section{Results}

\section{NBD Peptide Localization and Selective Inhibition of T24 Cancer Cells}

The ability of the NBD peptide to gain entry into the T24 cells and their stability inside the cells was determined using confocal microscopy after incubation of cells with the peptide for $10 \mathrm{~min}, 45 \mathrm{~min}, 4 \mathrm{~h}$ and 24 h. The NBD peptide tagged with FITC fluorochrome emits fluorescence upon intracellular localization and is not affected by $\mathrm{pH}$ changes in the endolysosomal compartments. The minimum time taken for NBD peptide cell penetration was $\leq 10 \mathrm{~min}$ where it was able to localize the cytosol and nucleus with detectable fluorescence. At $45 \mathrm{~min}$ of treatment, there were prominent signals from the NBD peptide in the cytoplasm and nucleus retaining cell morphology until 4 $\mathrm{h}$ of treatment. The T24 cells started to show aggregation at $24 \mathrm{~h}$ of treatment, however, the fluorescence signal was stable with detectable emissions from the peptide. Figure 1 shows that the NBD peptide was stable for up to $24 \mathrm{~h}$ of treatment and was capable of acting on the cell's internal machinery. The cytotoxicity was tested on NIH-3T3-L1, CHO and Vero (non-cancerous) cells along with T24 cancer cell line. NIH-3T3-L1, CHO and Vero cells were resistant to NBD peptide treatment $(P \leq$ $0.05)$. However, T24 BC cells were susceptible to NBD peptide treatment $(25,50,100 \mu \mathrm{M})$ at $48 \mathrm{~h}$ duration $(P \leq$ $0.05)$. The susceptibility was compared with the untreated control cells and standard drugs like cisplatin and gemcitabine (Fig. 2). The inhibition of T24 cell growth in MTT assay allowed us to determine the $\mathrm{IC}_{50}$ value as $18.5 \mu \mathrm{M}$ and this concentration was used to test the adjuvant capability of NBD peptide. A combination of NBD peptide along with the standard chemotherapeutic drugs was tested on T24 cells. The results showed higher susceptibility of T24 cells to the synergistic action of NBD: Cisplatin: Gemcitabine combination at $48 \mathrm{~h}(P \leq$ 0.05) than the individual agents (Fig. 3).

\section{NBD Peptide Elicits Cell Cycle Inhibition}

Flow cytometry was performed on T24 cells treated for $48 \mathrm{~h}$ with NBD peptide (12.5, 18.5 and $25 \mu \mathrm{M})$, standard chemotherapeutic drugs and the combination of NBD with standard chemotherapeutic drugs. Control represents the normal cell cycle progression in $\mathrm{T} 24$ cells. Treatment with the NBD peptide increases the accumulation of cells in the sub G0- G1 phase with an overall reduction in the number of events recorded. The 
standard drugs cisplatin shows an increase in the cells at sub G0- G1 and disruption of G2- M phase; gemcitabine shows an increase in the cells at sub G0G1 phase; dual action of cisplatin and gemcitabine shows accumulation of cells in the $S$ phase indicating a disruption of G2- $\mathrm{M}$ phase. The combination of NBD along with standard drugs indicates the effects of the individual agents combined. The NBD \& gemcitabine combination shows G2- M phase disruption which was absent in their individual effect and has increased the accumulation of cells in sub G0- G1 phase. The NBD \& standard drugs combination panel shows an overall reduction in the number of events and an increase of cells in sub G0- G1 phase. The histograms of flow cytometry (Fig. 4) and the number of events after gating are tabulated (Table 1).

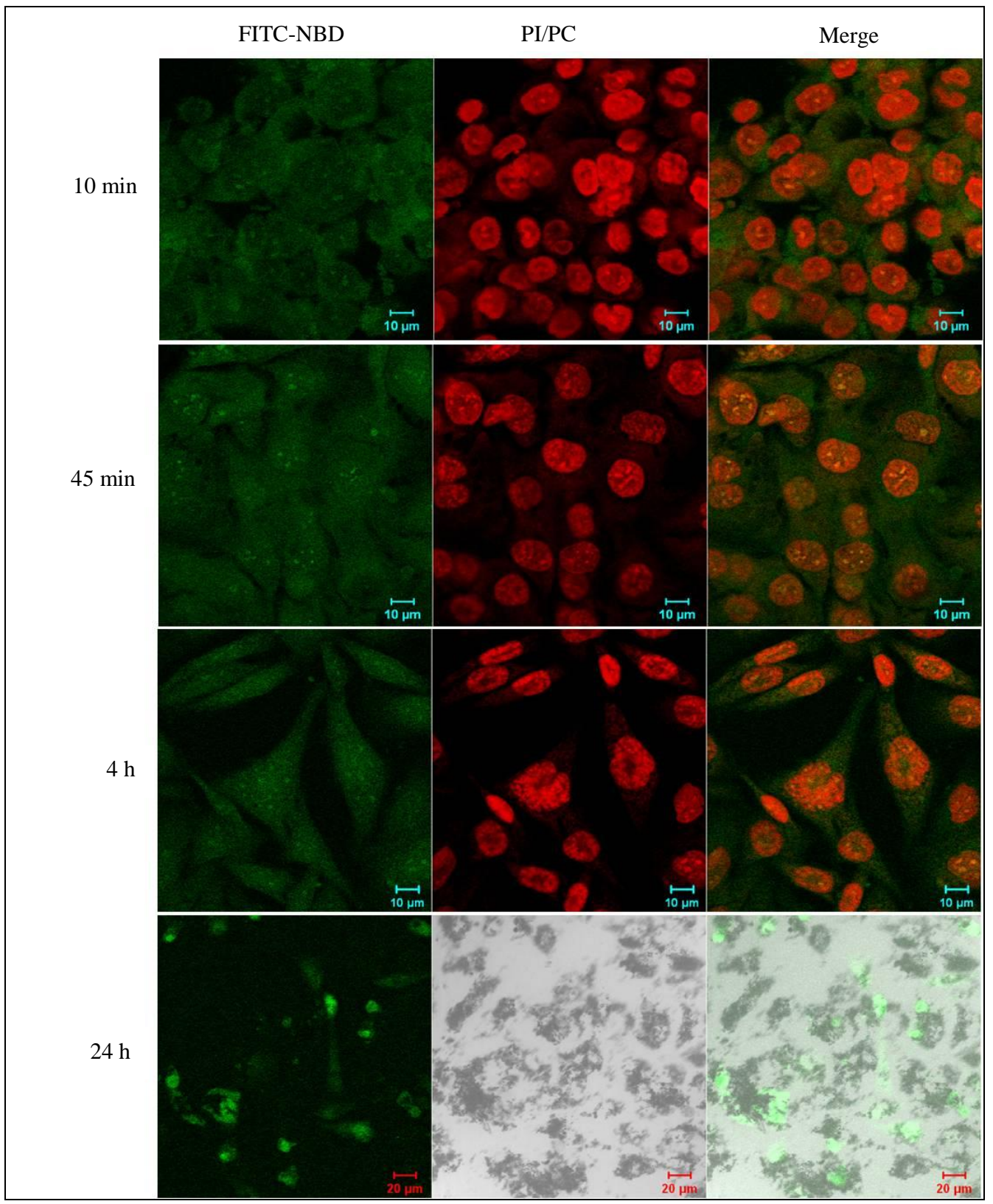

Fig. 1: NBD peptide localization in T24 cancer cells. Localization of NBD peptide in T24 cells under 40 and $20 \times$ objectives. FITCNBD tagged peptide $(20 \mu \mathrm{M})$ fluoresces upon localization (green). Nucleus was counterstained by propidium iodide (PI, red). The localization of FITC-NBD peptide in the nucleus along with PI, fluorescence emission is shown as a merge in yellow. At $24 \mathrm{~h}$ there was high cell aggregation after NBD treatment and PI nuclear staining was uneven and hence phase contrast (PC) images with FITC-NBD were shown 


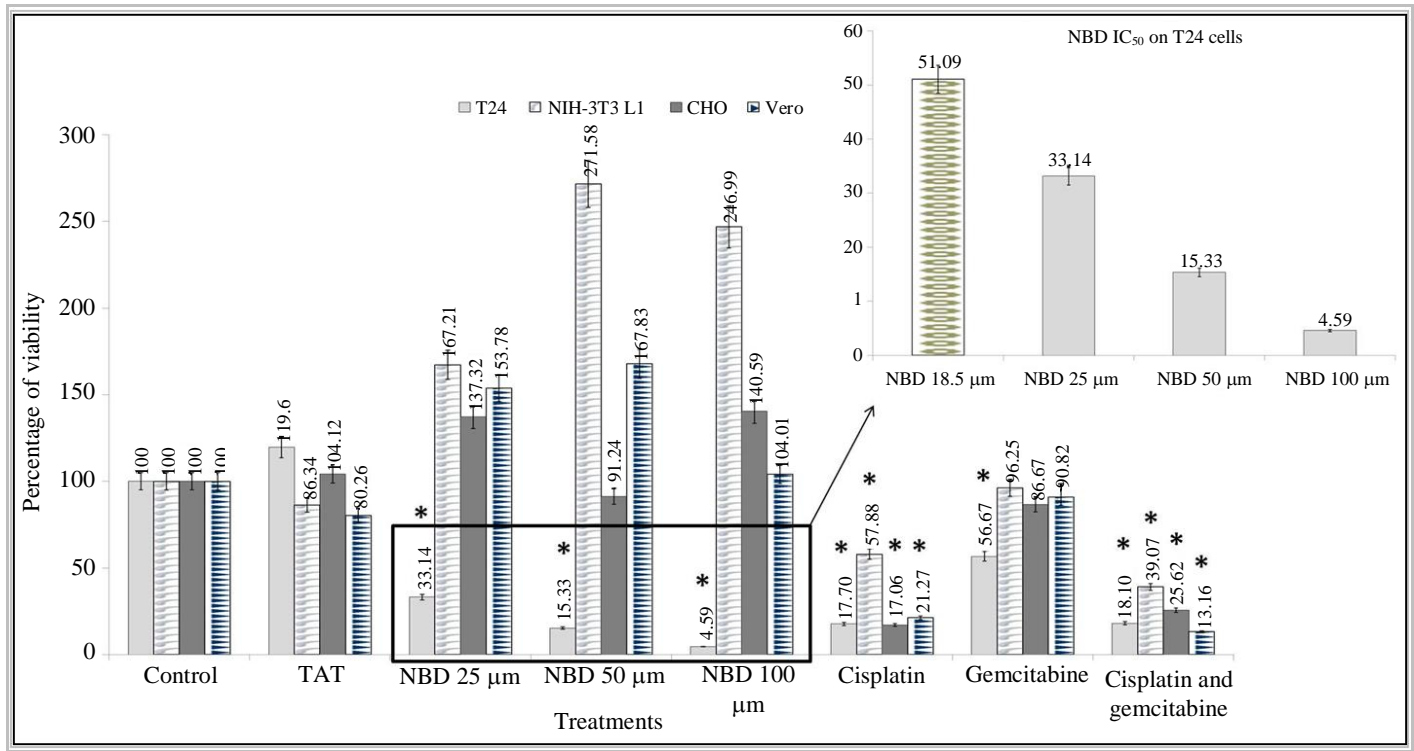

Fig. 2: Cytotoxicity of NBD peptide and standard drugs on T24, NIH-3T3-L1, CHO and Vero cells. T24 cells have been inhibited by NBD peptide and the standard drugs when compared to the non-cancerous cells (NIH-3T3-L1, CHO and Vero). Data are presented as Mean \pm SD of three independent experiments. The statistical significance is indicated by $*(P \leq 0.05)$. The dose response of the NBD peptide at $\mathrm{IC}_{50}$ has been shown as figure insert

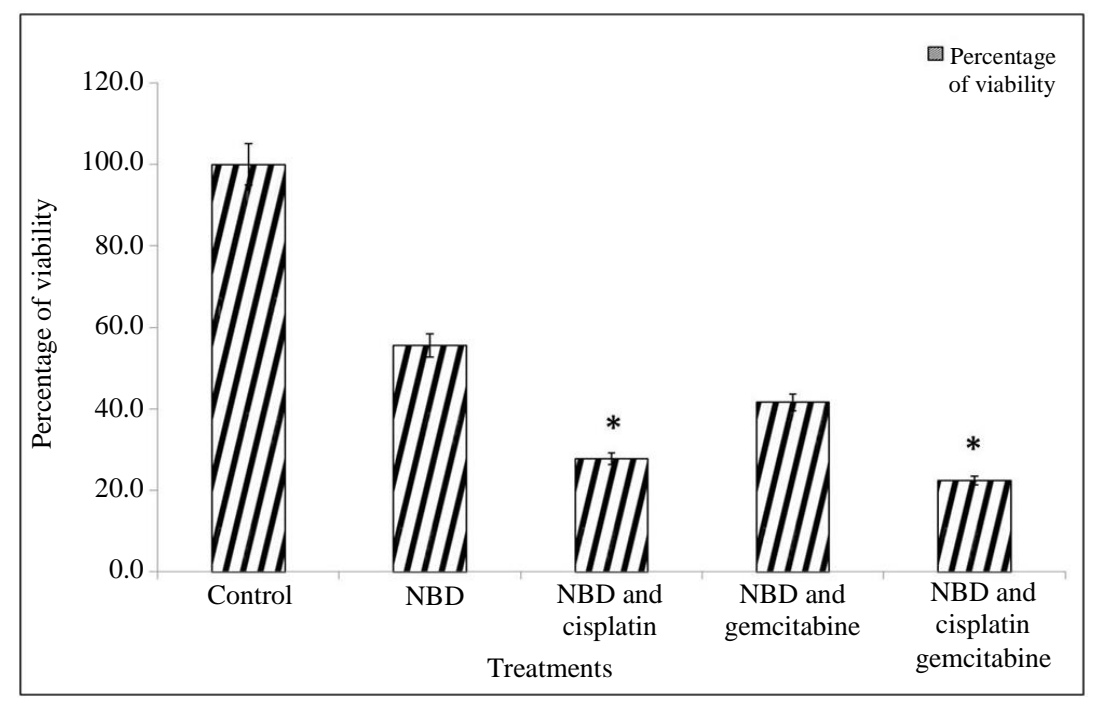

Fig. 3: Cytotoxicity of $\mathrm{IC}_{50}$ NBD peptide and a combination with standard drugs on T24 cells. The $\mathrm{IC}_{50}$ NBD peptide showed about $50 \%$, NBD and Cisplatin showed about 27\%, NBD and Gemcitabine showed about $41 \%$ and NBD and Cisplatin and Gemcitabine showed about $22 \%$ cell viability. Data are presented as Mean \pm SD of three independent experiments. The statistical significance is indicated by $*(P \leq 0.05)$

\section{NBD Peptide Induces Caspase-3 Independent Cell Death of T24 Cells and Inhibits Cell Migration}

The accumulation of sub G0-G1 population in cell cycle after NBD treatment led us to use acridine orange and ethidium bromide staining to reveal the mode of death induced by NBD peptide. The early or late apoptosis marked by the orange-yellow coloration was scanty in the standard drug panel and negligible in the combination treatment panel (Fig. 5). To confirm that there was no caspase activity we quantified the cysteine-aspartate proteases that are released when the cells undergo apoptosis. We tested the highest concentration of NBD peptide $(100 \mu \mathrm{M})$ on T24 cells for $48 \mathrm{~h}$. Negligible effect was observed with the combination of NBD and standard chemotherapeutic drugs when compared with untreated cells (Fig. 6). Similarly, the LDH release was quantified to assess cellular damage as it is a stable cytosolic enzyme, released into the culture medium upon cell lysis. Oxidation of lactate to pyruvate (reversible) is catalysed by LDH, 
forming NAD+ from NADH and thus the determination of $\mathrm{LDH}$ is based on the detection of NADH in the reaction. Thus Fig. 7 indicates T24 cell death by necrosis (resultant of ruptured plasma membrane) upon treatment with NBD and its combination with cisplatin and gemcitabine. Further confirmation for the non-apoptotic mode of death was by DAPI staining where there was no chromatin condensation at the nuclear membrane periphery except in combinations that contained cisplatin: NBD and cisplatin; NBD, cisplatin and gemcitabine (Fig. 8).

Table 1: Total number of recorded events/ cells after gating for cell cycle analysis by Flow cytometry

\begin{tabular}{|c|c|c|c|c|c|}
\hline \multirow[b]{2}{*}{ Treatments } & \multirow[b]{2}{*}{$\%$ Total } & \multicolumn{4}{|c|}{$\begin{array}{l}\text { Events }(\%) \\
\text { Cell cycle phases }\end{array}$} \\
\hline & & Sub G0-G1 & G0-G1 & $\mathrm{S}$ & G2-M \\
\hline Control & 91.32 & 1.58 & 72.62 & 9.23 & 8.07 \\
\hline $\operatorname{NBD}(12.5 \mu \mathrm{M})$ & 84.97 & 9.9 & 55.07 & 9.13 & 10.52 \\
\hline $\mathrm{IC}_{50} \mathrm{NBD}(18.5 \mu \mathrm{M})$ & 71.72 & 6.8 & 49.54 & 11.95 & 3.95 \\
\hline $\operatorname{NBD}(25 \mu \mathrm{M})$ & 82.85 & 19.36 & 45.44 & 10.13 & 8.04 \\
\hline Cisplatin & 85.60 & 14.5 & 51.66 & 12.22 & 7.53 \\
\hline Gemcitabine & 84.19 & 9.83 & 62.31 & 4.78 & 7.51 \\
\hline Cisplatin and Gemcitabine & 93.86 & 10.16 & 42.78 & 17.17 & 4.11 \\
\hline $\mathrm{IC}_{50}$ NBD: Cisplatin & 92.51 & 18.76 & 38.76 & 22.86 & 12.1 \\
\hline IC 50 NBD: Gemcitabine & 93.41 & 25.69 & 41.82 & 19.59 & 6.58 \\
\hline IC50 NBD: Cisplatin: Gemcitabine & 76.57 & 17.26 & 30.35 & 21.5 & 7.44 \\
\hline
\end{tabular}

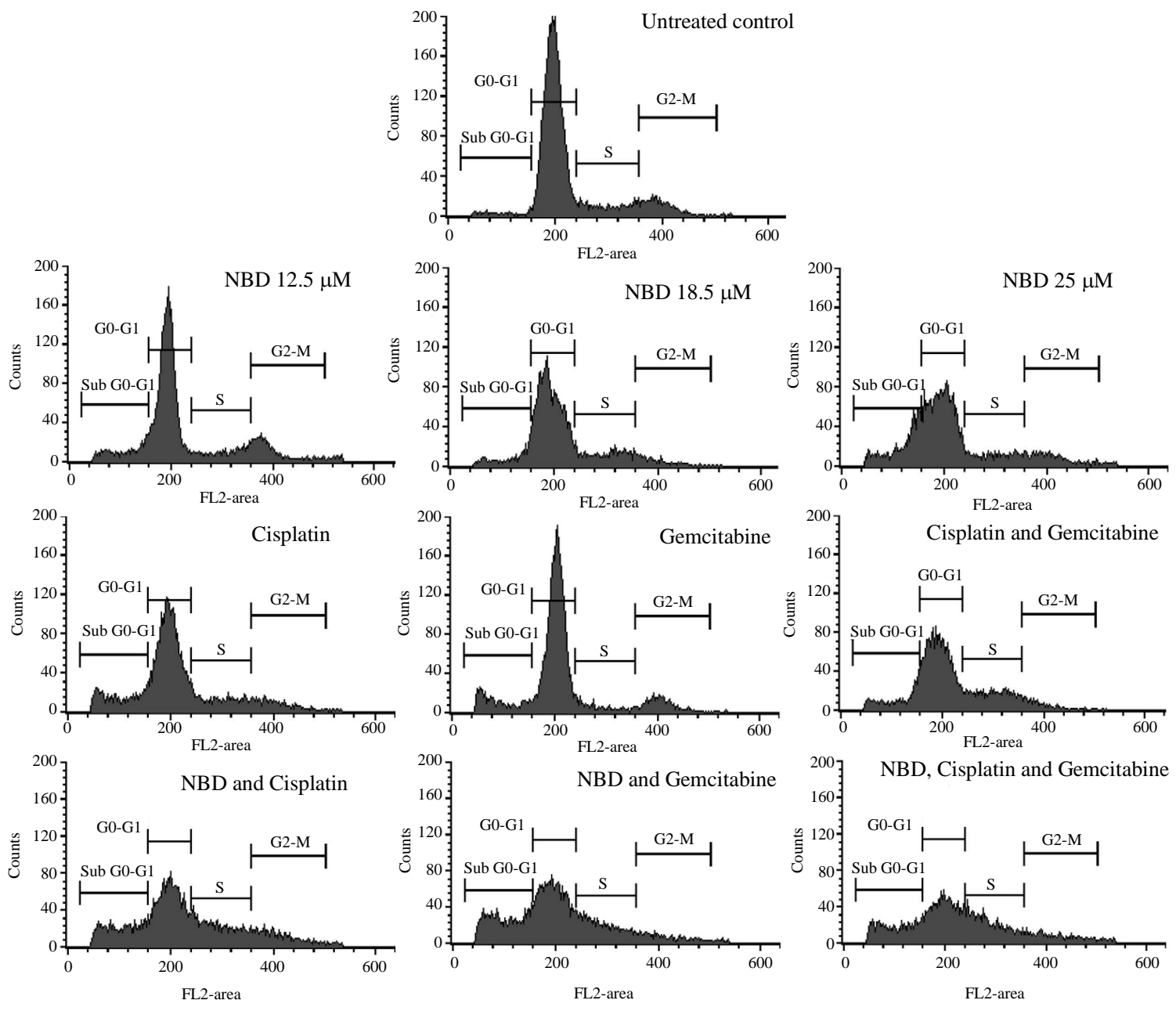

Fig. 4: NBD peptide effect on the cell cycle of T24 cells 

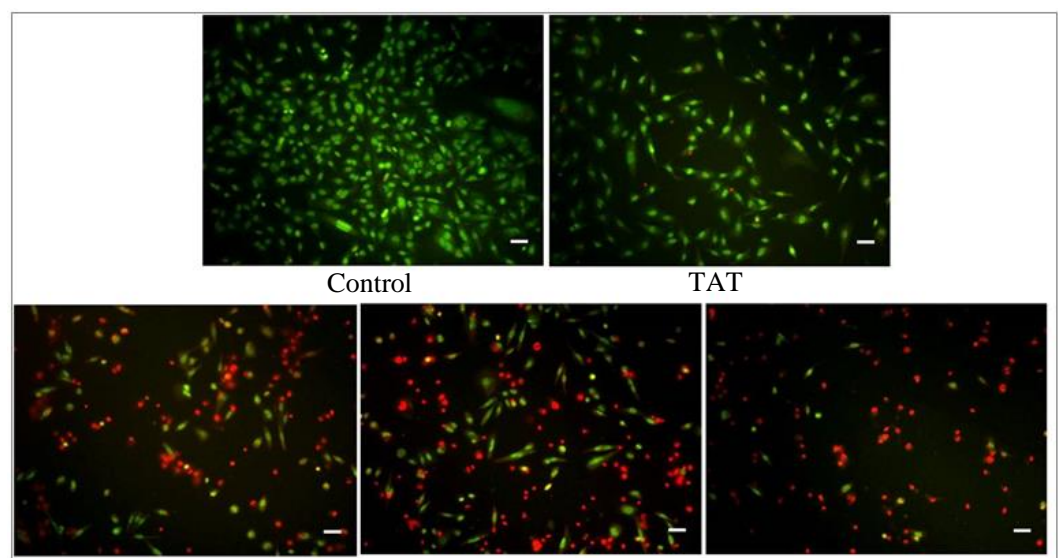

NBD $12.5 \mu \mathrm{M}$

NBD $18.5 \mu \mathrm{M}$

NBD $25 \mu \mathrm{M}$
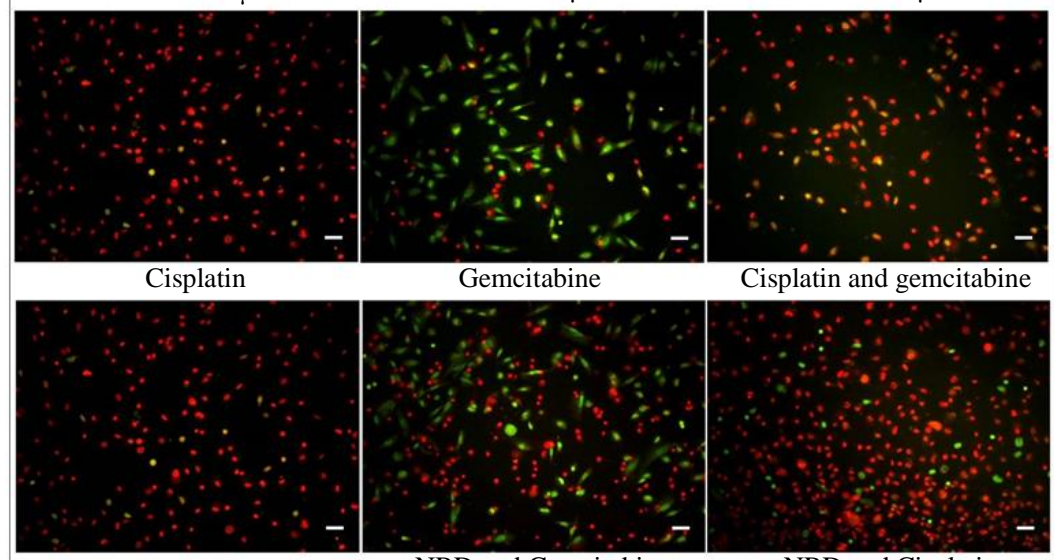

Gemcitabine

Cisplatin and gemcitabine

NBD and Cisplatin
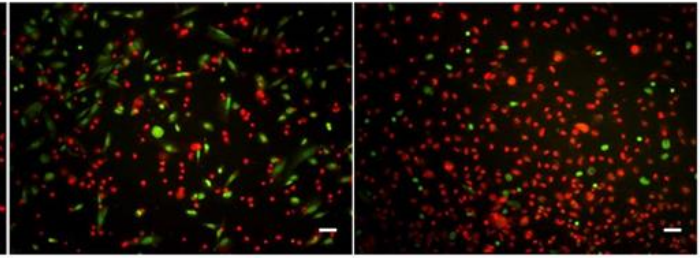

NBD and Gemcitabine

NBD and Cisplatin

and gemcitabine

Fig. 5: NBD peptide imparts necrotic mode of cell death in BC. Acridine orange and ethidium bromide staining of the IC 50 NBD peptide treated T24 cells shows 50\% viable cells (green) and 50\% necrotic cells (red) under $10 \times$ objectives. Scale bar indicates $20 \mu \mathrm{M}$. The cells that show orange-yellow color indicate early or late apoptotic cells. The combination of cisplatin and gemcitabine had a mix of apoptotic and necrotic cells as shown by the cell color. Treatment with IC50 NBD peptide and the standard drugs shows red colored cells indicating cell necrosis

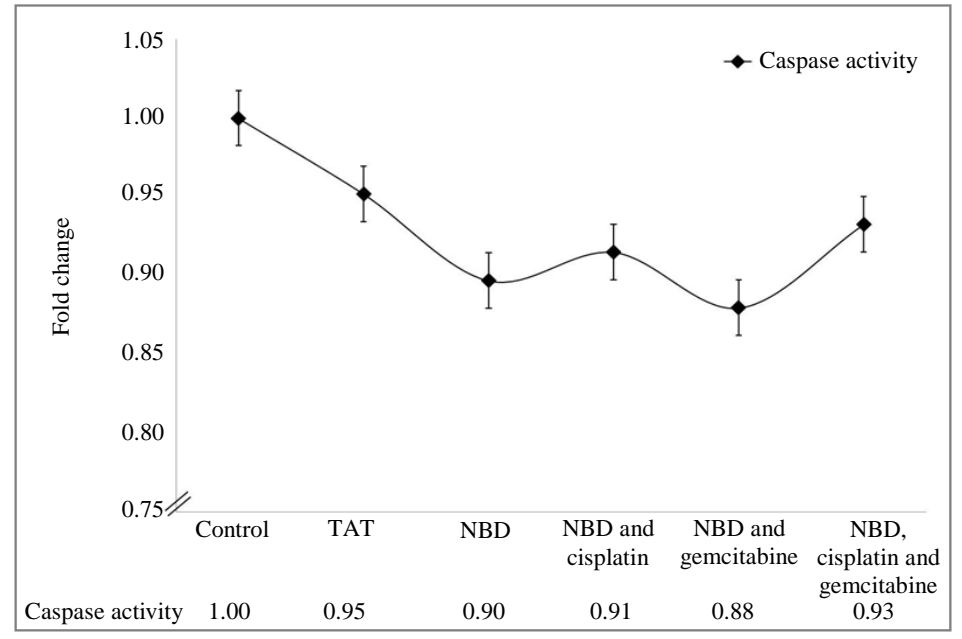

Fig. 6: Apoptosis detection using caspases. Caspase enzyme activity (arbitrary units) tested at the highest concentration of NBD peptide on T24 cells and the combination. Data are presented as Mean \pm SD of three independent experiments. None of the groups showed statistical significance $(P \geq 0.05)$ 


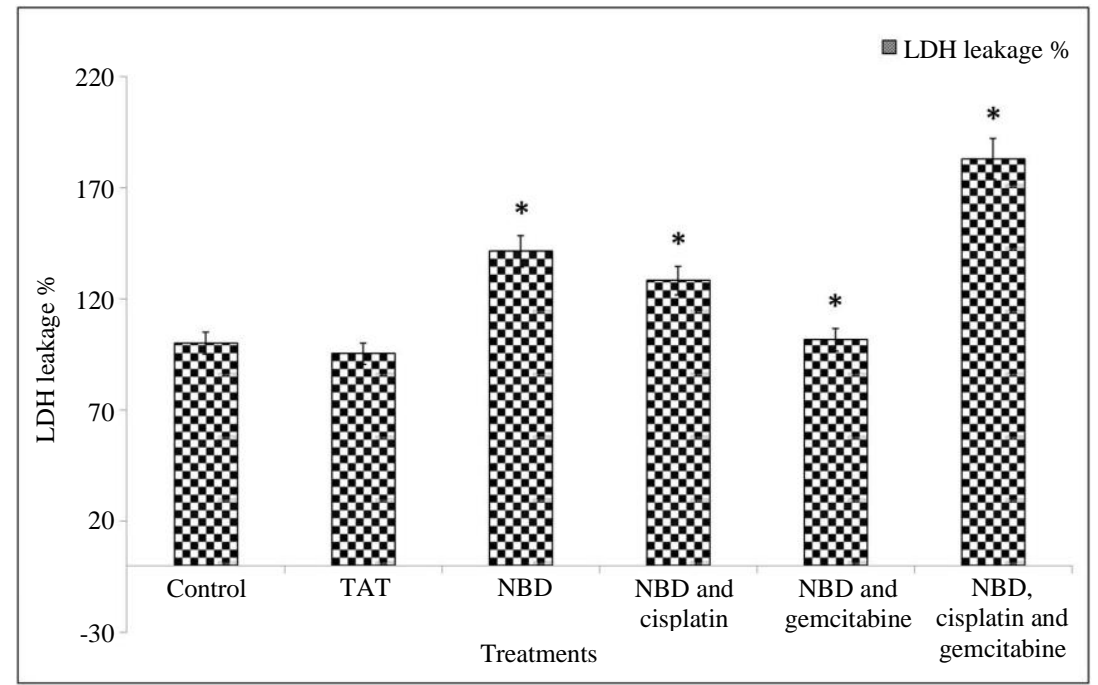

Fig. 7: Assessing necrosis using LDH release. The percentage release of LDH increases when compared to the control group as the plasma membrane integrity and permeability is compromised upon treatment with NBD peptide and in combination with standard drugs. Data are presented as Mean \pm SD of three independent experiments. The statistical significance is indicated by $*(P \leq 0.05)$
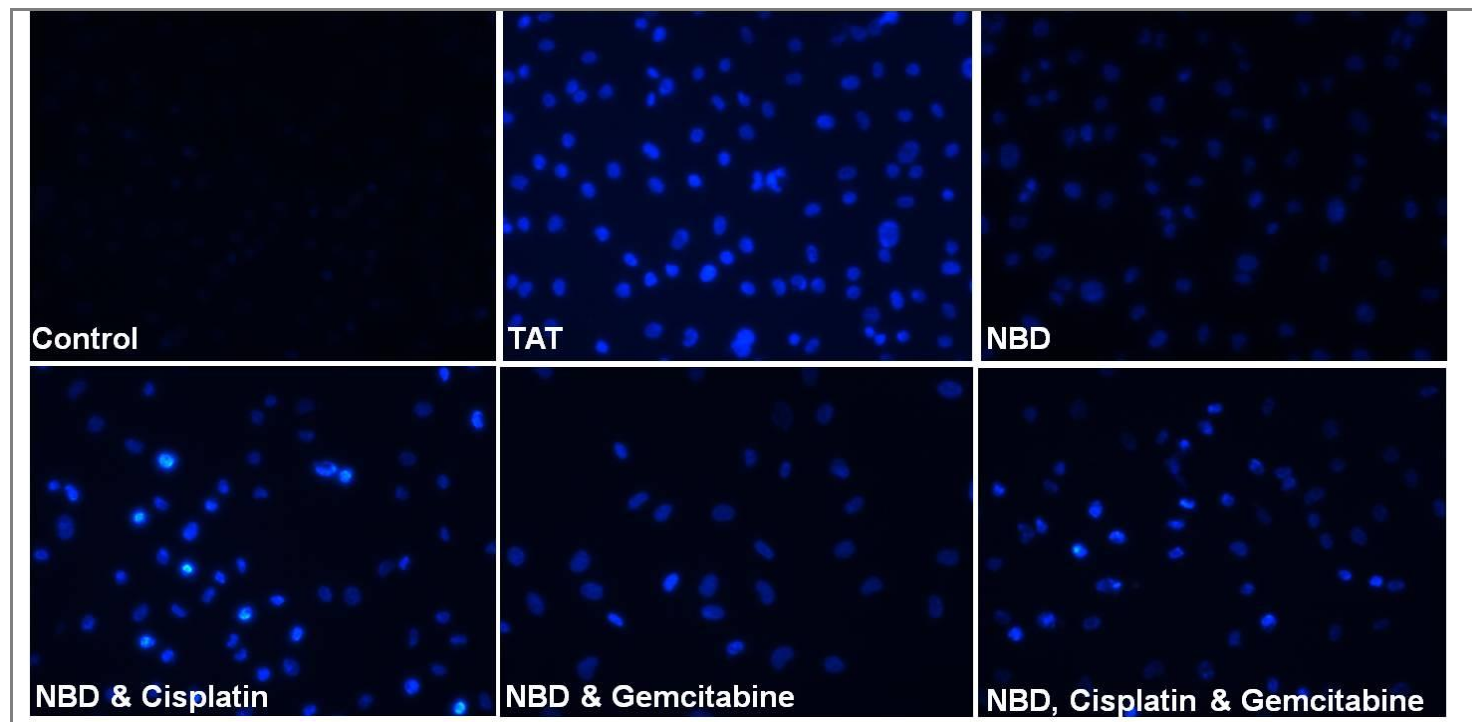

Fig. 8: Detecting the apoptotic nuclei by DAPI staining. Apoptotic nuclei have characteristic features of condensed or fragmented chromatin that are intensely stained by DAPI. Control T24 cells, TAT, NBD, NBD and gemcitabine show negligible amounts of DAPI fluorescence indicating necrotic mode of cell death. Intense chromatin staining is observed in NBD and cisplatin and NBD, cisplatin and gemcitabine treated T24 cells showing a mixed population of apoptotic and necrotic cells

Cancer metastasis is mimicked by the process of wound healing on the monolayer of cells as they require the same phenomenon of proliferation and migration. In our study, the ability of T24 cells to convalesce to their viable state after NBD treatment was demonstrated using cell migration technique. The T24 cells after treatment with NBD peptide, standard drugs and the combination showed significant cell migration inhibition in wound closure when compared to the untreated cells. NBD peptide, when used at the $\mathrm{IC}_{50}$ concentrations of $18.5 \mu \mathrm{M}$ was unable to restrict the migration of T24 cells and hence the highest concentration of NBD peptide (100 $\mu \mathrm{M})$ was used in the wound closure assay. The highest concentration of NBD peptide combination along with standard drugs had better inhibition of cell migration than the individual agents (Fig. 9). 


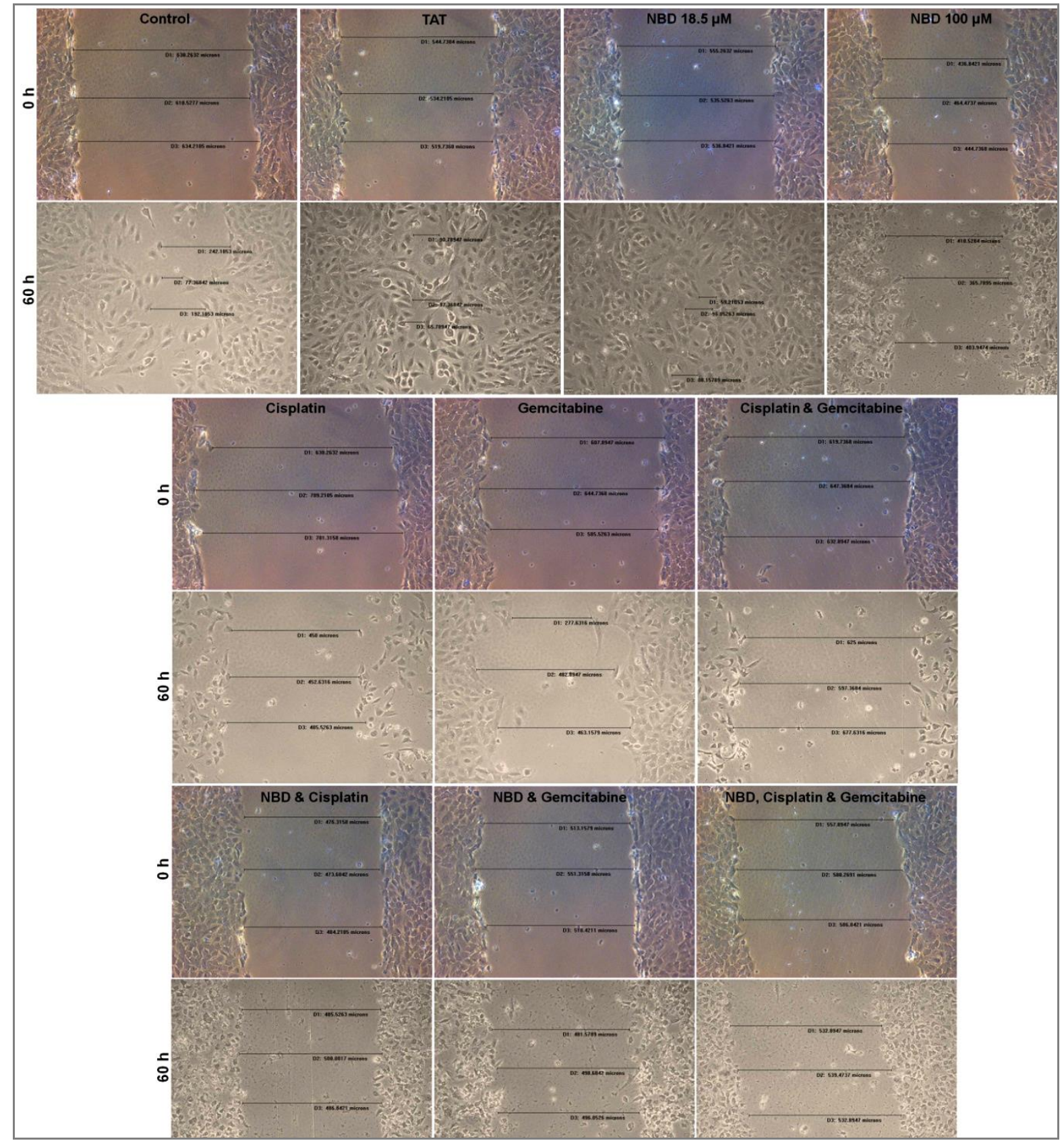

Fig. 9: NBD peptide, standard drugs and combination effect on T24 cell migration. T24 cells after treatment with NBD peptide (100 $\mu$ M) and standard drugs showed minimal recovery from the inflicted wound when compared to the untreated control cells

\section{Discussion}

$\mathrm{BC}$ is a recurrent disease and lacks thorough investigations (Mukherjee et al., 2015). The tissue microenvironment is a niche that comprises various signaling factors that are involved in several regulatory functions of a cell. BC has highly active NF- $\mathrm{KB}$ along with other transcription factors (Degoricija et al., 2014). During $\mathrm{BC}$ initiation presence of aberrant NF- $\mathrm{kB}$ in the tumor milieu has been reported (Levidou et al., 2008;
Zhu et al., 2017; Mukherjee et al., 2017). Targeted therapy is sought after in the treatment of BC (Jones et al., 2016) overexpression of NF- $\mathrm{KB}$ heterodimers can be used to differentiate cancer cells from normal cells. Previously, we were able to show that the NF-kB RelA preferably binds to other dimers of the family other than p50 during BC progression (Durairajan et al., 2018). Since the involvement of the NF- $\kappa B$ heterodimers in BC progression was evident, we utilized this to explore the treatment potential by targeting this pathway. 
NBD peptide was identified to have antiinflammatory properties by acting as indirect NF- $\mathrm{B}$ inhibitor (Gilmore, 2006; Gilmore and Garbati, 2011). $\mathrm{NF}-\kappa \mathrm{B}$ inhibition either directly or indirectly will affect the basal NF- $\mathrm{KB}$ activity required for cell survival and upon its inhibition will lead to toxicity (Davé et al., 2007). Few studies investigating NBD peptide have eradicated this concern where prolonged NBD peptide administration ameliorated inflammatory responses in inflammatory animal models effectively without side effects (Jimi et al., 2004; di Meglio et al., 2005) while retaining the basal level activity of the $\mathrm{NF}-\kappa \mathrm{B}$ heterodimer to perform the regulatory functions (Jana et al., 2017; May et al., 2000). NBD peptide was able to reduce skeletal muscle atrophy and tumor induced muscle wasting dosedependently with the ability to decrease the tumor burden (Madonna et al., 2012; Wysong et al., 2011).

NBD peptide core amino acids determine its activity and any changes in the core region disrupt its antiinflammatory activity, rendering it inactive (Dai et al., 2004). Analysis of binding energy hot spots between those on NEMO (Nuclear Factor kappa B (NF-кB) essential modulator) and IKK $\beta$ (I $\mathrm{B}$ kinase subunit $\beta$ ) interacting interface identified an NBD (NEMO Binding Domain) region on IKK $\beta$ to contain the highest concentration of hot-spot residues (W739, W741 and L742). The residing region of these residues creates a druggable binding site on NEMO (Golden et al., 2013). In the present study, NBD peptide was fused with HIV coat protein fragment, TAT to achieve cell penetration. This peptide fragment, NBD inhibits the growth of T24 BC cells. According to our hypothesis, we observed dose-dependent inhibition of the T24 cells with half maximal inhibition at $48 \mathrm{~h}$, while the non-cancerous (NIH-3T3-L1 cells, CHO and Vero) cells did not show any cytotoxicity (Fig. 2). The specificity of NBD peptide towards cancer cells makes it evident that it targets a specific molecule in T24 BC cells that is uncommon in the non-cancerous cell lines. The viability assay confirmed dose-dependent cell death and the NBD peptide's ability to interrupt cellular processes to bring about cell death. The unaffected growth of the noncancerous cells after NBD treatment was high when compared with the untreated control group. The statistical significance of the T24 cancer cell line $(P \leq$ $0.05)$ is due to the decrease in the number of viable cells that are compared with the untreated control group.

NBD peptide localization in the nucleus was suggestive of the interference to cell cycle. Accumulation of the cells in Sub G0-G1phase indicated necrosis of cells caused by NBD peptide treatment. Combining NBD peptide with standard drugs showed decrease in the overall number of events in all cell cycle phases. Further, differential staining of T24 cells with acridine orange and ethidium bromide revealed majority of cells emitting red fluorescence post NBD peptide treatment suggesting necrosis. Ethidium bromide is known to shift its fluorescence upon binding to intracellular DNA after entering cells with damaged membranes in necrotic cells (Liu et al., 2015; Vethakanraj et al., 2015). This was confirmed by the negligible caspase activity at the highest concentration of the NBD peptide tested compared to the untreated control cells (Fig. 6). Thus acridine orange/ethidium bromide staining, caspase activity, LDH release, DAPI staining confirmed that there was no apoptosis in T24 cells after NBD peptide treatment and also inhibited cell migration in vitro. To the best of our knowledge, this is the first report on NBD peptide to have necrotic activity in T24 bladder cancer cell line. Our observations in this study was in accordance with other studies that state different cell lines do respond differently to a treatment based on their cancer phenotype (McConnell et al., 2015); the factors that cause a peptide to act differently in a tumor microenvironment (Pan et al., 2014); the amino acid difference from the originally reported NBD peptide (May et al., 2000; Dai et al., 2004; May et al., 2002) and the different cell penetrating peptide tags that allow them to act unlike their original counterparts (Shaheen et al., 2018).

Currently, peptide based trials have been predicted to be clinically successful in urological cancers (Obara et al., 2018) and the ability of NBD peptide to sensitize cancer cells to chemotherapy have been reported in pancreatic cancer (Holcomb et al., 2008). Our study was in conformity with another study that combined NBD peptide with other chemotherapeutics like cisplatin and gemcitabine producing higher rates of proliferation inhibition than the peptide or drug alone (Ndikuyeze et al., 2014). Definitive use of NBD peptide determines its function to act as a cell protective agent with minimal adverse effects (Rehman et al., 2003) or to act as an antiinflammatory/anti-cancer agent. This dynamic change in action for NBD could be due to more than just inhibition of activated NF- $\kappa \mathrm{B}$ (Cerón et al., 2010). Our study suggests that the mechanism of NBD peptide action varied from each cell type analyzed. This only emphasizes the need for more mechanistic studies that allows characterization of the physiological and immunological responses with NBD treatment in BC.

\section{Conclusion}

We investigated NBD peptide in BC since the available chemotherapeutics lack specificity with adverse side effects. In our study, we have shown that NBD peptide selectively reduces the proliferation of $\mathrm{BC}$ cells in vitro by necrosis after localization. NBD peptide lacked cytotoxicity towards non-cancerous cell lines across all tested doses. The combination treatment of 
NBD peptide along with cisplatin and gemcitabine showed stronger inhibition than single drug treatment. Though we need further investigations to understand NBD peptide's mechanism of action, its use as an anticancer agent in the recurrent and often chemoresistant $\mathrm{BC}$ seems promising.

\section{Acknowledgement}

This work was supported by GATE- Young faculty research grant funding from Sri Ramachandra Institute of Higher Education and Research (Deemed to be University), Chennai, India to authors CEJW and DJDG. Author SD was awarded chancellor fellowship from Sri Ramachandra Institute of Higher Education and Research (Deemed to be University), Chennai, India.

\section{Author's Contributions}

Sankari Durairajan and Charles Emmanuel Jebaraj W: Conceived, designed and performed the experiments, analyzed the data, contributed reagents/materials/analysis tools, prepared figures and/or tables, performed and interpreted formal analysis, authored or reviewed drafts of the paper and approved the final draft.

Kalaiselvi Periyandavan, George Priya Doss C, Dicky John Davis G, Hannah Rachel Vasanthi A, Gayathri Thiruvengadam and Thanka Jhonson: Analyzed the data, contributed reagents/materials/analysis tools, performed and interpreted formal analysis, reviewed drafts of the paper and approved the final draft.

\section{Ethics}

All authors have read and approved the final version of this manuscript. There are no ethical issues to declare that could arise after the publication of this manuscript.

\section{References}

Abdel-Mageed, A.B., 2003. NF- $\kappa$ B-dependent gene expression of proinflammatory cytokines in T24 cells: Possible role in interstitial cystitis. Urol. Res., 31: 300-305. DOI: 10.1007/s00240-003-0339-9

Antoni, S., J. Ferlay, I. Soerjomataram, A. Znaor and A. Jemal et al., 2017. Bladder cancer incidence and mortality: A global overview and recent trends. Eur. Urol., 71: 96-108.

DOI: $10.1016 /$ j.eururo.2016.06.010

Baima, E.T., J.A. Guzova, S. Mathialagan, E.E. Nagiec and M.M. Hardy et al., 2010. Novel insights into the cellular mechanisms of the anti-inflammatory effects of NF-[kappa] B Essential Modulator (NEMO) binding domain peptides. J. Biol. Chem., 285: 13498-506. DOI: 10.1074/jbc.M109.099895
Buchwald, Z.S. and J.A. Efstathiou, 2015. Immunotherapy and radiation - a new combined treatment approach for bladder cancer? Bladder Cancer, 1: 15-27. DOI: 10.3233/BLC-150014

Burger, M., J.W. Catto, G. Dalbagni, H.B. Grossman and H. Herr et al., 2012. Epidemiology and risk factors of urothelial bladder cancer. Eur. Urol., 63: 234-241. DOI: 10.1016/j.eururo.2012.07.033

Cerón, J.M., J. Contreras-Moreno, E. Puertollano, G.A. De Cienfuegos and M.A. Puertollano et al., 2010. The antimicrobial peptide cecropin A induces caspase-independent cell death in human promyelocytic leukemia cells. Peptides, 31: 1494-1503. DOI: 10.1016/j.peptides.2010.05.008

Choi, M., S. Rolle, M. Wellner, M.C. Cardoso and C. Scheidereit et al., 2003. Inhibition of NF- $\kappa$ B by a TAT-NEMO-binding domain peptide accelerates constitutive apoptosis and abrogates LPS-delayed neutrophil apoptosis. Blood, 102: 2259-2267.

DOI: 10.1182/blood-2002-09-2960

Chong, M.W., K.D. Gu, P.K. Lam, M. Yang and W.F. Fong, 2000. Study on the cytotoxicity of microcystin-LR on cultured cells. Chemosphere, 41: 143-147. DOI: 10.1016/S0045-6535(99)00402-6

Dai, S., T. Hirayama, S. Abbas and Y. Abu-Amer, 2004. The IкB Kinase (IKK) inhibitor, NEMO-binding domain peptide, blocks osteoclastogenesis and bone erosion in inflammatory arthritis. J. Biol. Chem., 279: 37219-37222. DOI: 1074/jbc.C400258200

Davé, S.H., J.S. Tilstra, K. Matsuoka, F. Li and T. Karrasch et al., 2007. Amelioration of chronic murine colitis by peptide-mediated transduction of the I $\kappa \mathrm{B}$ kinase inhibitor NEMO binding domain peptide. J. Immunol., 179: 7852-7859.

DOI: $10.4049 /$ jimmunol.179.11.7852

Degoricija, M., M. Šitum, J. Korać, A. Miljković and K.

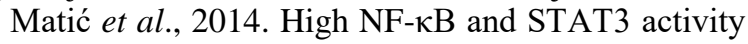
in human urothelial carcinoma: A pilot study. World J. Urol., 32: 1469-1475.

DOI: $10.1007 \% 2 F s 00345-014-1237-1$

di Meglio, P., A. Ianaro and S. Ghosh, 2005. Amelioration of acute inflammation by systemic administration of a cell-permeable peptide inhibitor of NF- $\mathrm{KB}$ activation. Arthritis. Rheumatol., 52: 951-958. DOI: 10.1002/art.20960

Durairajan, S., C.E.J. Walter, M.D. Samuel, D. Palani and D.J.G. Davis et al., 2018. Differential expression of NF- $\kappa \mathrm{B}$ heterodimer RelA/p50 in human urothelial carcinoma. PeerJ., 6: e5563-e5563. DOI: $10.7717 /$ peerj.5563

Elumalai, P., D.N. Gunadharini, K. Senthilkumar, S. Banudevi and R. Arunkumar et al., 2012. Induction of apoptosis in human breast cancer cells by nimbolide through extrinsic and intrinsic pathway. Toxicol. Lett., 215: 131-142. DOI: $10.1016 /$ j.toxlet.2012.10.008 
Fechner, G., F.G.E. Perabo, D.H. Schmidt, L. Haase and E. Ludwig et al., 2003. Preclinical evaluation of a radiosensitizingeffect of gemcitabine in p53 mutant and p53 wildtype bladder cancer cells. Urology, 61: 468-473. DOI: 10.1016/S0090-4295(02)02156-8

Gao, K., D.L. Dai, M. Martinka and G. Li, 2006. Prognostic significance of nuclear factor- $\kappa \mathrm{B}$ p105/p50 in human melanoma and its role in cell migration. Cancer Res., 66: 8382-8388.

DOI: 10.1158/0008-5472.CAN-05-4402

Gaurnier-Hausser, A., R. Patel, A.S. Baldwin, M.J. May and N. Mason, 2011. NEMO Binding Domain peptide inhibits constitutive $\mathrm{NF}-\kappa \mathrm{B}$ activity and reduces tumor burden in a canine model of relapsed, refractory Diffuse Large B-Cell Lymphoma. Clin. Cancer Res., 17: 4661-4671.

DOI: 10.1158/1078-0432.CCR-10-3310

Gilmore, T.D. and M.R. Garbati, 2011. Inhibition of NF$\kappa \mathrm{B}$ Signaling as a Strategy in Disease Therapy. In: $\mathrm{NF}-\kappa \mathrm{B}$ in Health and Disease: Current Topics in Microbiology and Immunology, Karin, M. (Ed.), Springer, Berlin, Heidelberg, pp: 245-263.

Gilmore, T.D., 2006. Introduction to NF-кB: Players, pathways, perspectives. Oncogene, 25: 6680-6684. DOI: $10.1038 /$ sj.onc. 1209954

Golden, M.S., S.M. Cote, M. Sayeg, B.S. Zerbe and E.A. Villar et al., 2013. Comprehensive experimental and computational analysis of binding energy hot spots at the NF- $\kappa \mathrm{B}$ essential modulator/IKK $\beta$ proteinprotein interface. J. Am. Chem. Soc., 135: 6242-6256. DOI: $10.1021 /$ ja400914z

Guallar-Garrido, S. and E. Julián, 2020. Bacillus Calmette-Guérin (BCG) therapy for bladder cancer: An update. Immunotargets Ther., 9: 11-11.

DOI: 10.2147/ITT.S202006

Holcomb, B., M. Yip-Schneider and C.M. Schmidt, 2008. The role of nuclear factor $\kappa \mathrm{B}$ in pancreatic cancer and the clinical applications of targeted therapy. Pancreas, 36: 225-235. DOI: 10.1097/MPA.0b013e31815b3207

Hong, S., S. Yum, H.J. Yoo, S. Kang and J.H. Yoon et al., 2012. Colon-targeted cell-permeable NF- $\mathrm{BB}$ inhibitory peptide is orally active against experimental colitis. Mol. Pharm., 9: 1310-1319. DOI: 10.1021/mp200591q

Ianaro, A., M. Tersigni, G. Belardo, S. Di Martino and M. Napolitano et al., 2009. NEMO-binding domain peptide inhibits proliferation of human melanoma cells. Cancer Lett., 274: 331-336.

DOI: 10.1016/j.canlet.2008.09.038

Ishaq, M., M.A. Khan, K. Sharma, G. Sharma and R.K. Dutta et al., 2014. Gambogic acid induced oxidative stress dependent caspase activation regulates both apoptosis and autophagy by targeting various key molecules (NF- $\mathrm{B}$, Beclin-1, p62 and NBR1) in human bladder cancer cells. Biochim. Biophys. Acta Gen. Subj., 1840: 3374-3384.

DOI: $10.1016 /$ j.bbagen.2014.08.019
Jakobsson, L., G. Chebil, N.A. Marzouka, F. Liedberg and G. Sjödahl, 2018. Low frequency of intratumor heterogeneity in bladder cancer tissue microarrays. Bladder Cancer, 4: 327- 37. DOI: $10.3233 /$ BLC-180176

Jana, A., N.L. Krett, G. Guzman, A. Khalid and O. Ozden et al., 2017. NF- $\mathrm{KB}$ is essential for activininduced colorectal cancer migration via upregulation of PI3K-MDM2 pathway. Oncotarget, 8: 37377-37393. DOI: $10.18632 /$ oncotarget.16343

Jimi, E., K. Aoki, H. Saito, F. D'Acquisto and M.J. May et al., 2004. Selective inhibition of $\mathrm{NF}-\kappa \mathrm{B}$ blocks osteoclastogenesis and prevents inflammatory bone destruction in vivo. Nat. Med., 10: 617-624.

DOI: $10.1038 / \mathrm{nm} 1054$

Jones, R.T., K.M. Felsenstein and D. Theodorescu, 2016. Pharmacogenomics: Biomarker-directed therapy for bladder cancer. Urol. Clin. North. Am., 43: 77-86. DOI: 10.1016/j.ucl.2015.08.007

Karin, M., Y. Cao, F.R. Greten and Z.W. Li, 2002. NF$\kappa \mathrm{B}$ in cancer: From innocent bystander to major culprit. Nat. Rev. Can., 2: 301-310. DOI: $10.1038 / \mathrm{nrc} 780$

Kaufman, D.S., W.U. Shipley and A.S. Feldman, 2009. Bladder cancer. Lancet, 374: 239-249.

DOI: 10.1016/S0140- 6736(09)60491-8

Levidou, G., A.A. Saetta, P. Korkolopoulou, P. Papanastasiou and K. Gioti et al., 2008. Clinical significance of nuclear factor (NF)- $\kappa B$ levels in urothelial carcinoma of the urinary bladder. Virchows. Arch., 452: 295-304. DOI: $10.1007 / \mathrm{s} 00428-007-0560-y$

Li, M., S. Song, S. Li, J. Feng and Z. Hua, 2015. The blockade of NF- $\mathrm{B}$ activation by a specific inhibitory peptide has a strong neuroprotective role in a sprague-dawley rat kernicterus model. J. Biol. Chem., 290: 30042-30052.

DOI: $10.1074 /$ jbc.M115.673525

Liu, K., P.C. Liu, R. Liu and X. Wu, 2015. Dual AO/EB staining to detect apoptosis in osteosarcoma cells compared with flow cytometry. Med. Sci. Monit. Basic. Res., 21: 15-20.

DOI: 10.1016/j.bbrc.2015.07.047

Long, Y.M., K. Chen, X.J. Liu, W.R. Xie and H. Wang, 2009. Cell-permeable Tat-NBD peptide attenuates rat pancreatitis and acinus cell inflammation response. World J. Gastroenterol, 15: 561-569. DOI: $10.3748 /$ wjg. 15.561

Lu, C.S., G.S. Shieh, C.T. Wang, B.H. Su and Y.C. Su et al., 2017. Chemotherapeutics-induced Oct4 expression contributes to drug resistance and tumor recurrence in bladder cancer. Oncotarget, 8: 30844-30858. DOI: 10.18632/oncotarget.9602 
Ma, T., Z. Wang, Y. Guo and D. Pei, 2009. The Cterminal pentapeptide of Nanog tryptophan repeat domain interacts with $\mathrm{Nac1}$ and regulates stem cell proliferation but not pluripotency. J. Biol. Chem., 284: 16071-16081. DOI: 10.1074/jbc.M109.005041

Madonna, G., C.D. Ullman, G. Gentilcore, G. Palmieri and P.A. Ascierto, 2012. NF- $\mathrm{KB}$ as potential target in the treatment of melanoma. J. Transl. Med., 10: 1-8. DOI: $10.1186 / 1479-5876-10-53$

May, M.J., F. D'acquisto, L.A. Madge, J. Glöckner and J.S. Pober et al., 2000. Selective inhibition of NF$\kappa \mathrm{B}$ activation by a peptide that blocks the interaction of NEMO with the IкB kinase complex. Science, 289: $1550-1554$.

DOI: $10.1126 /$ science. 289.5484 .1550

May, M.J., R.B. Marienfeld and S. Ghosh, 2002. Characterization of the IKB-kinase NEMO binding domain. J. Biol. Chem., 277: 45992-6000.

DOI: $10.1074 /$ jbc.M206494200

McConnell, E.J., B. Devapatla, K. Yaddanapudi and K.R. Davis, 2015. The soybean-derived peptide lunasin inhibits non-small cell lung cancer cell proliferation by suppressing phosphorylation of the retinoblastoma protein. Oncotarget, 6: 4649-4662. DOI: $10.18632 /$ oncotarget.3080

Mukherjee, N., E. Cardenas, R. Bedolla and R. Ghosh, 2017. SETD6 regulates NF- $\mathrm{BB}$ signaling in urothelial cell survival: Implications for bladder cancer. Oncotarget, 8: 15114-15125.

DOI: 10.18632 /oncotarget.14750

Mukherjee, N., T.J. Houston, E. Cardenas and R. Ghosh, 2015. To be an ally or an adversary in bladder cancer: The NF- $\mathrm{kB}$ story has not unfolded. Carcinogenesis, 36: 299-306. DOI: 10.1093/carcin/bgu321

Ndikuyeze, G.H., A. Gaurnier-Hausser, A.S. Patel, R. Baldwin and M.J. May et al., 2014. A phase I clinical trial of systemically delivered NEMO binding domain peptide in dogs with spontaneous activated B-cell like diffuse large B-cell lymphoma. PLoS One, 9: e95404-e95404.

DOI: 10.1371/journal.pone.0095404

Obara, W., M. Kanehira, T. Katagiri, R. Kato and Y. Kato et al., 2018. Present status and future perspective of peptide-based vaccine therapy for urological cancer. Cancer Sci., 109: 550-559.

DOI: $10.1111 /$ cas. 13506

Pan, C.Y., C.N. Lin, M.T. Chiou, C.Y. Yu and J.Y. Chen et al., 2014. The antimicrobial peptide pardaxin exerts potent anti-tumor activity against canine perianal gland adenoma. Oncotarget, 6: 2290-2301. DOI: $10.18632 /$ oncotarget.2959

Pettenati, C. and M.A. Ingersoll, 2018. Mechanisms of BCG immunotherapyand its outlook for bladder cancer. Nat. Rev. Urol., 15: 615-625.

DOI: $10.1038 / \mathrm{s} 41585-018-0055-4$
Rehman, K.K., S. Bertera, R. Bottino, A.N. Balamurugan and J.C. Mai et al., 2003. Protection of islets by in situ peptide-mediated transduction of the IкB kinase inhibitor Nemo-binding domain peptide. J. Biol. Chem., 278: 9862-9868.

DOI: 10.1074/jbc.M207700200

Richardson, P., T. Hideshima, C. Mitsiades and K. Anderson, 2004. Proteasome inhibition in hematologic malignancies. Ann. Med., 36: 304-314. DOI: $10.1080 / 07853890410030877$

Shaheen, F., M. Nadeem-ul-Haque, A. Ahmed, S.U. Simjee and A. Ganesan et al., 2018. Synthesis of breast cancer targeting conjugate of temporinSHa analog and its effect on pro-and antiapoptotic protein expression in MCF-7 cells. Peptides, 106: 68-82.

DOI: $10.1016 /$ j.peptides.2018.07.002

Soloway, M.S., 2013. Bladder cancer: Lack of progress in bladder cancer-what are the obstacles? Nat. Rev. Urol., 10: 5-6. DOI: 10.1038/nrurol.2012.219

Tajmohammadi, I., J. Mohammadian, M. Sabzichi, S. Mahmuodi and M. Ramezani et al., 2019. Identification of Nrf2/STAT3 axis in induction of apoptosis through sub-G1 cell cycle arrest mechanism in HT-29 colon cancer cells. J. Cell. Biochem. DOI: $10.1002 /$ jcb. 28678

Tian, B., Z. Wang, Y. Zhao, D. Wang and Y. Li et al., 2008. Effects of curcumin on bladder cancer cells and development of urothelial tumors in a rat bladder carcinogenesis model. Cancer Lett., 264: 299-308. DOI: 10.1016/j.canlet.2008.01.041

Vethakanraj, H.S., T.A. Babu, G.B. Sudarsanan, P.K. Duraisamy and S.A. Kumar, 2015. Targeting ceramide metabolic pathway induces apoptosis in human breast cancer cell lines. Biochem. Biophys. Res. Commun., 464: 833-839. DOI: $10.12659 /$ MSMBR.893327

Wang, C., H.B. Li, S. Li, L.L. Tian and D.J. Shang, 2012. Antitumor effects and cell selectivity of temporin-1CEa, an antimicrobial peptide from the skin secretions of the Chinese brown frog (Rana chensinensis). Biochimie, 94: 434-441.

DOI: 10.1016/j.biochi.2011.08.011

Wang, L., F. Kang, J. Li, J. Zhang and B. Shan, 2013. Overexpression of p65 attenuates celecoxib-induced cell death in MDA-MB-231 human breast cancer cell line. Cancer Cell Int., 13: 14-14.

DOI: 10.1186/1475-2867-13-14

Wang, Y., F. Hao, Y. Nan, L. Qu and W. Na et al., 2018. PKM2 inhibitor shikonin overcomes the cisplatin resistance in bladder cancer by inducing necroptosis. Int. J. Biol. Sci., 14: 1883-1891.

DOI: $10.7150 /$ ijbs. 27854 
Woolbright, B.L., M.B.S. Ayres and J.A. Taylor III, 2018. Metabolic changes in bladder cancer. Urol. Oncol., 36: 327-337.

DOI: $10.1016 /$ j.urolonc.2018.04.010

Wysong, A., S.A. Asher, X. Yin, M.R. Gore and L. Weinstein, et al., 2011. Selective inhibition of NFkappa-B with NBD peptide reduces tumor-induced wasting in a murine model of cancer cachexia in vivo. J. Cancer Sci. Ther., 3: 22-29.

DOI: $10.4172 / 1948-5956.1000052$

Yeh, H.C., C.H. Huang, S.F. Yang, C.C. Li and L.L. Chang et al., 2010. Nuclear factor- $\mathrm{KB}$ activation predicts an unfavourable outcome in human upper urinary tract urothelial carcinoma. BJU Int., 106: 1223-1229.

DOI: 10.1111/j.1464-410X.2010.09210.x
Zhang, Q., M.J. Lenardo, D. Baltimore, 2017. 30 years of NF-kB: A blossoming of relevance to human pathobiology. Cell, 168: 37-57. DOI: $10.1016 /$ j.cell.2016.12.012

Zhu, J., Y. Li, C. Chen, J. Ma and W. Sun et al., 2017. NF-KB p65 overexpression promotes bladder cancer cell migration via FBW7-mediated degradation of RhoGDI $\alpha$ protein. Neoplasia, 19: 672-683.

DOI: $10.1016 /$ j.neo.2017.06.002 